\title{
Atomic Force Microscopy Investigation of DNA Extracted from the Vegetative Forms and the Viable but Nonculturable Forms of Mycoplasma gallisepticum S6
}

Olga A. Chernova, Maxim V. Trushin*, Alexey A. Mouzykantov, and Vladislav M. Chernov

Kazan Institute of Biochemistry and Biophysics, Russian Academy of Sciences, Kazan, Russian Federation

E-mail: mtrushin@mail.ru

Received September 25, 2008; Revised October 17, 2008; Accepted October 17, 2008; Published November 2,2008

Recent studies show that mycoplasmas have various programs of life. This means that changes in morphology and genome expression may occur once the environment of these microorganisms becomes extremely altered. In this article, we report on changes in the DNA molecule obtained from the vegetative forms and the viable but nonculturable (VBNC) forms of Mycoplasma gallisepticum S6. Atomic force microscopy studies show that the above-mentioned forms of the mycoplasma have different values of DNA parameters (height: $0.461 \pm 0.141$ and $0.236 \pm 0.069 \mathrm{~nm}$; width: $2.221 \pm 0.286$ and $1.291 \pm$ $0.705 \mathrm{~nm}$ for the vegetative and the VBNC forms, respectively). We suppose that the observed phenomenon may be connected with the process of adaptation of these bacteria to severe environments.

KEYWORDS: mycoplasma, atomic force microscopy, DNA, viable but nonculturable (VBNC) forms, vegetative forms

\section{INTRODUCTION}

Mycoplasmas (class Mollicutes) are unique bacteria that are characterized by a small cell size, a reduced genome, and the absence of a cell wall[1]. Despite their seeming simplicity, little is known about the precise mechanisms that possess the virulence and pathogenicity of mycoplasmas. Recently, the principal ability to change morphologic, genetic, and biochemical features during stress conditions was reported for mycoplasma cells[2,3] as well as for other bacteria. These changes may include a reduction of the cell size, a disappearance of cell polarity, and an alteration of expression of some genes[4,5]. These modified cells were referred to as the "viable but nonculturable" (VBNC) forms.

We found that changes in DNA structure take part during adaptation of Mycoplasma gallisepticum S6 to stress conditions. In the VBNC forms of this mycoplasma, we detected the nucleotide sequence (582 bp) with two open-reading frames that is not registered in the vegetative forms of M. gallisepticum S6. 
Because of the revealed DNA modifications, it is reasonable to expect some global changes in the structure of DNA, particularly in its secondary structure. Therefore, in the present study, we intend to compare the height and other DNA characteristics of the DNA molecules extracted from the vegetative forms and the VBNC forms of M. gallisepticum S6 as measured by atomic force microscopy (AFM).

\section{MATERIALS AND METHODS}

The M. gallisepticum S6 strain was obtained from the N.F. Gamalei Research Institute of Epidemiology and Microbiology (Moscow, Russia).

M. gallisepticum S6 cells grown in the liquid-modified Edward's nutrient medium for 3 days and grown in deficient medium for 26 weeks (cells adapted to unfavorable growth conditions) were used to compare their DNA properties. The liquid-modified Edward's nutrient medium[3] consisted of the following components (in \%): tryptose, $2 ; \mathrm{NaCl}, 0.5 ; \mathrm{KCl}, 0.13$; Tris basic, 0.3 ; serum of horse blood, 10;

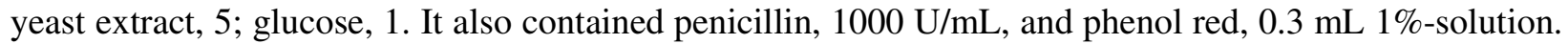
In the case of the deficient medium, glucose, yeast extract, and serum of horse blood were excluded.

For AFM studies, DNA was extracted from M. gallisepticum S6 cells grown in the full-growth medium and in the deficient one (the vegetative forms and the VBNC forms, respectively). To extract DNA, the following procedures were applied. Mycoplasma cells were centrifuged at $9000 \mathrm{~g}$ for $20 \mathrm{~min}$. The pellet was resuspended in TES buffer (Tris-HCl $10 \mathrm{~m} M$, EDTA $1 \mathrm{~m} M, \mathrm{NaCl} 100 \mathrm{mM}$ ), SDS (1-2\%) was added to the solution, shaken, and stored at $37^{\circ} \mathrm{C}$. An equal volume of aqueous phenol-chloroform mixture (1:1) was added to the obtained cell lysate. Aqueous phase was separated by centrifugation and the second extraction with chloroform-isoamyl alcohol mixture (24:1) was performed. DNA was precipitated with 2.5 volume of ethanol (96\%). The pellet was dissolved in TE buffer (Tris-HCl $10 \mathrm{~m} M$, Na-EDTA $1 \mathrm{~m} M, \mathrm{pH}$ 8.0). For additional purification, the solution was incubated with RNAse (20 $\mu \mathrm{g} / \mathrm{mL}$, Serva, Germany) for $30 \mathrm{~min}$ at $37^{\circ} \mathrm{C}$ and then with proteinase K $(50 \mu \mathrm{g} / \mathrm{mL}$, Sigma, USA) for 30 min at $37^{\circ} \mathrm{C}$. After the enzymatic treatment, DNA was again extracted with the chloroform-isoamyl alcohol mixture and precipitated with 2.5 volume of ethanol (96\%). DNA concentration was detected in agarose gel electrophoresis using standard DNA samples (Fermentas, Lithuania).

A buffer containing $5 \mathrm{mM} \mathrm{MgCl} 2$ and $10 \mathrm{mM}$ Tris was used to dilute DNA samples to special concentrations $(0.15-0.5 \mathrm{ng} / \mu \mathrm{L})$. The upper layer of mica (Advanced Technologies Center, Moscow, Russia) was eliminated with scotch and DNA samples $(3 \mu \mathrm{L})$ were placed onto the mica for 1 min. Then the mica with DNA was rinsed twice with redistilled water and, after each rinsing, it was dried with the pressurized air. Images were acquired in air by a Solver $\mathrm{P} 47 \mathrm{H}$ atomic force microscope (NT-MDT, Moscow, Russia) operating in the tapping mode using fpN11S cantilevers ( $\mathrm{r}=10 \mathrm{~nm}$, Advanced Technologies Center, Moscow, Russia). The height, Mag (signal from lock-in amplifier), RMS (signal from RMS detector), and Phase (signal from the phase detector) were performed with the Nova 1.0.26 RC1 software (NT-MDT, Moscow, Russia).

Data are given as mean \pm SD. The Kolmogorov-Smirnov test was applied to test whether our data yielded a normal distribution. Significant differences in the results were evaluated by applying Student's $t$ test. Calculations were made using the Origin 8.0 software for Windows.

\section{RESULTS}

Dozens of DNA samples prepared as described above have been analyzed by AFM in the tapping mode in air. In many cases, the substrate appeared to be uniform with DNA molecules adsorbed onto the surface of the substrate. Rarely, however, hills and holes appeared on the surface of a mica (Fig. 1); we consider that this kind of defect can be explained by nonhomogenous distribution of the ions dissolved in the buffer containing the DNA molecules. 


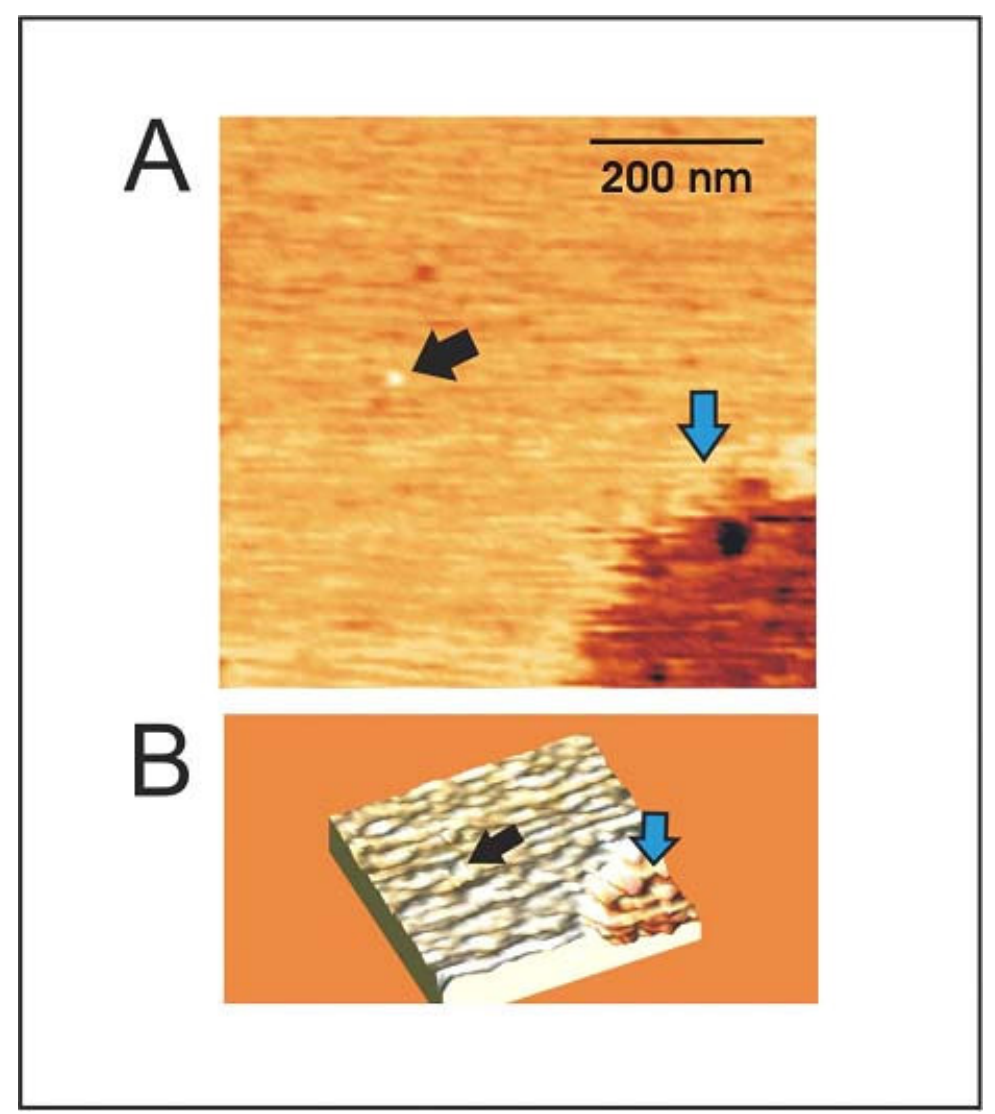

FIGURE 1. The substrate surface of a mica (the area without the DNA molecules, 0.6 $\mu \mathrm{m}^{2}$ ). Hills and holes are indicated by black and blue arrows, respectively. (A) 2D image, the hole zone is in the right bottom; (B) 3D image.

Fig. 2 presents 2D images of DNA obtained from the vegetative forms of $M$. gallisepticum S6. In many cases, the DNA molecules were folded into compact shapes (black arrows). The general sizes of the DNA globules range between 200 and $400 \mathrm{~nm}$ (in diameter) and about $100 \mathrm{~nm}$ in height. However, smaller DNA globules were also registered (Fig. 2A,B). Also, there were DNA molecules with untwining parts (Fig. 2, green arrows) and DNAs in unstressed form (Fig. 2, red arrows). 2D images of DNA extracted from the VBNC forms of $M$. gallisepticum S6 are presented in Fig. 3. The individual DNA molecules $(\mathrm{A}-\mathrm{C})$ as well as the sites of DNA entwinement $(\mathrm{D}, \mathrm{E})$ can be seen in the figure. The differences are dictated by concentration of the molecules $(0.15$ and $0.45 \mathrm{ng} / \mu \mathrm{L}$, respectively).

Table 1 presents data on the calculation of DNA height and width (full width at half-maximum height). Interestingly, the height of the DNA molecules taken from the VBNC forms of the mycoplasma was significantly less: $0.236 \pm 0.069 \mathrm{~nm}$. Similarly, the direct observation gave us the following values of DNA widths: $15.547 \pm 2.002$ and $9.037 \pm 935 \mathrm{~nm}$ for the vegetative forms and the VBNC forms of $M$. gallisepticum S6, respectively. After the compilation adjustment, the sizes of DNA widths became less. We also calculated DNA widths according to formula suggested by Margeat and coworkers[6]:

$$
\mathrm{S}=2 \mathrm{x}\left(R \times D+D^{2} / 4\right)^{1 / 2}
$$

where $R$ is the tip radius; $D$ is the measured height of the DNA molecule studied, $\mathrm{S}$ is DNA width at the half-maximum seen on the section of the DNA molecule. The performed statistical analysis (Table 2) showed significant differences between values calculated for the vegetative forms and the VBNC forms of the mycoplasma under study. 


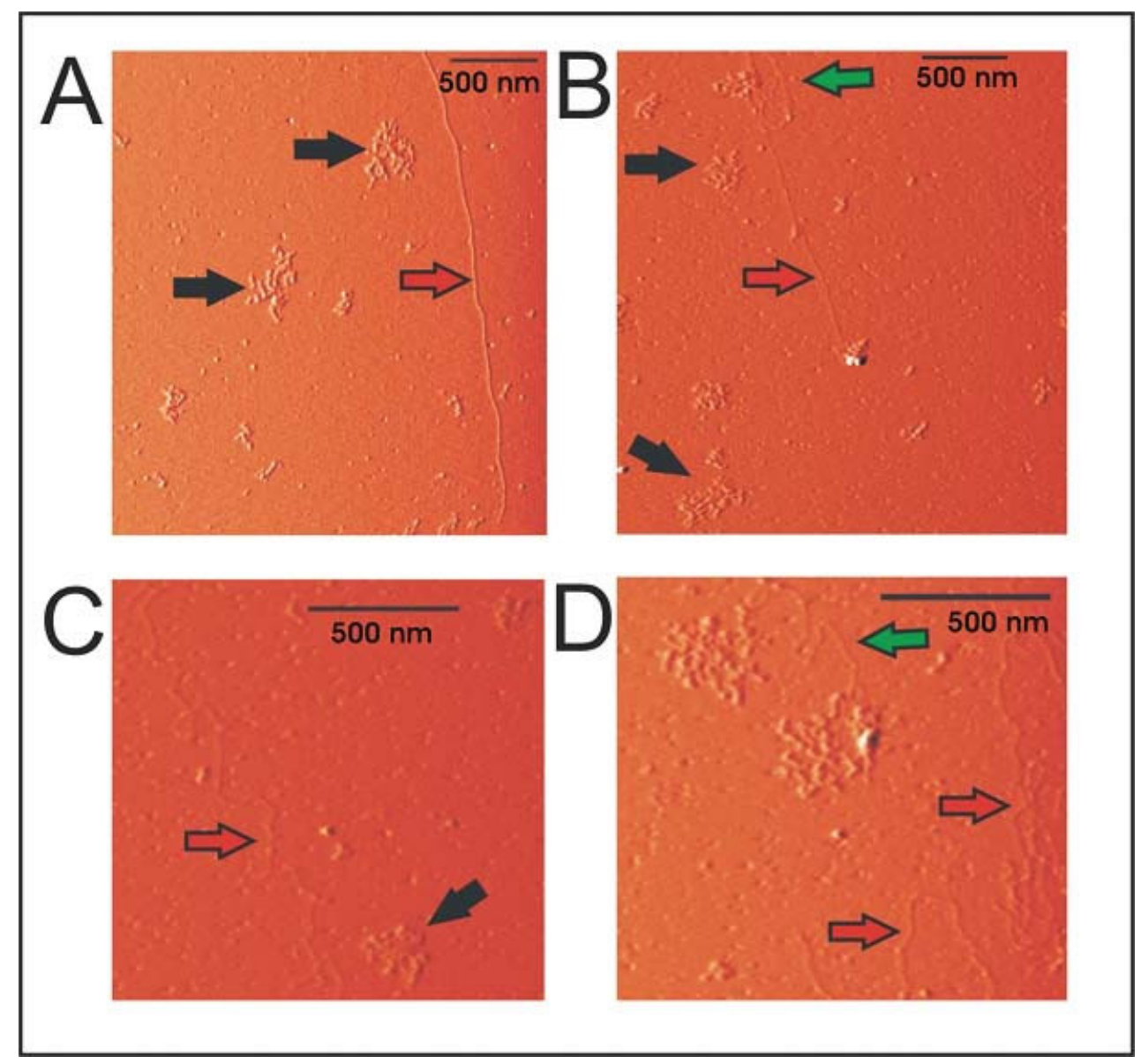

FIGURE 2. Noncontact tapping mode AFM of DNA obtained from the vegetative forms of M. gallisepticum S6 in air. (A-D) 2D images recorded from the different areas of scanning. The black arrow, the DNA molecules fold into compact shapes; green arrow, DNA in hemicompact form; red arrow, DNA in unstressed form.

\section{DISCUSSION}

Imaging of individual biological polymers by AFM has been used productively to reveal details of their structure in a number of cases[7]. In this article, we describe for the first time the use of AFM to probe the organization of the genetic apparatus of M. gallisepticum S6. We have examined the topology of the DNA molecules obtained from the vegetative forms and the VBNC forms of mycoplasma. The uniformity of the substrate used allowed us to achieve 2D images of the DNA molecules with high resolution. The detection of the DNA molecules folded into compact shapes (Fig. 2, black arrows) allowed us to account for the stability of the complexes. The similar compact shapes were reported for the single-stranded $\phi X-$ 174 DNA molecules[8]. However, the sizes of the DNA globules obtained from the vegetative forms of M. gallisepticum S6 were greater (at least twofold) than those from $\phi \mathrm{X}-174$; the variations can probably be explained by the differences in the genome size of two microorganisms. However, the nature of these compact shapes needs the further investigation.

With the use of the special software processing, AFM images of the DNA molecules obtained from the VBNC forms of M. gallisepticum S6 were analyzed. A few remarks can be made from the analysis. While the elevations upon substrate (indicated by black arrows in Fig. 3D,E) can be explained by DNA tangles, it is not possible to say the same about single molecules of DNA (Fig. 3A-C). It is reasonable to suggest that the sites of elevations (indicated by yellow arrows in Fig. 3A-C) present areas of DNA-Mg 


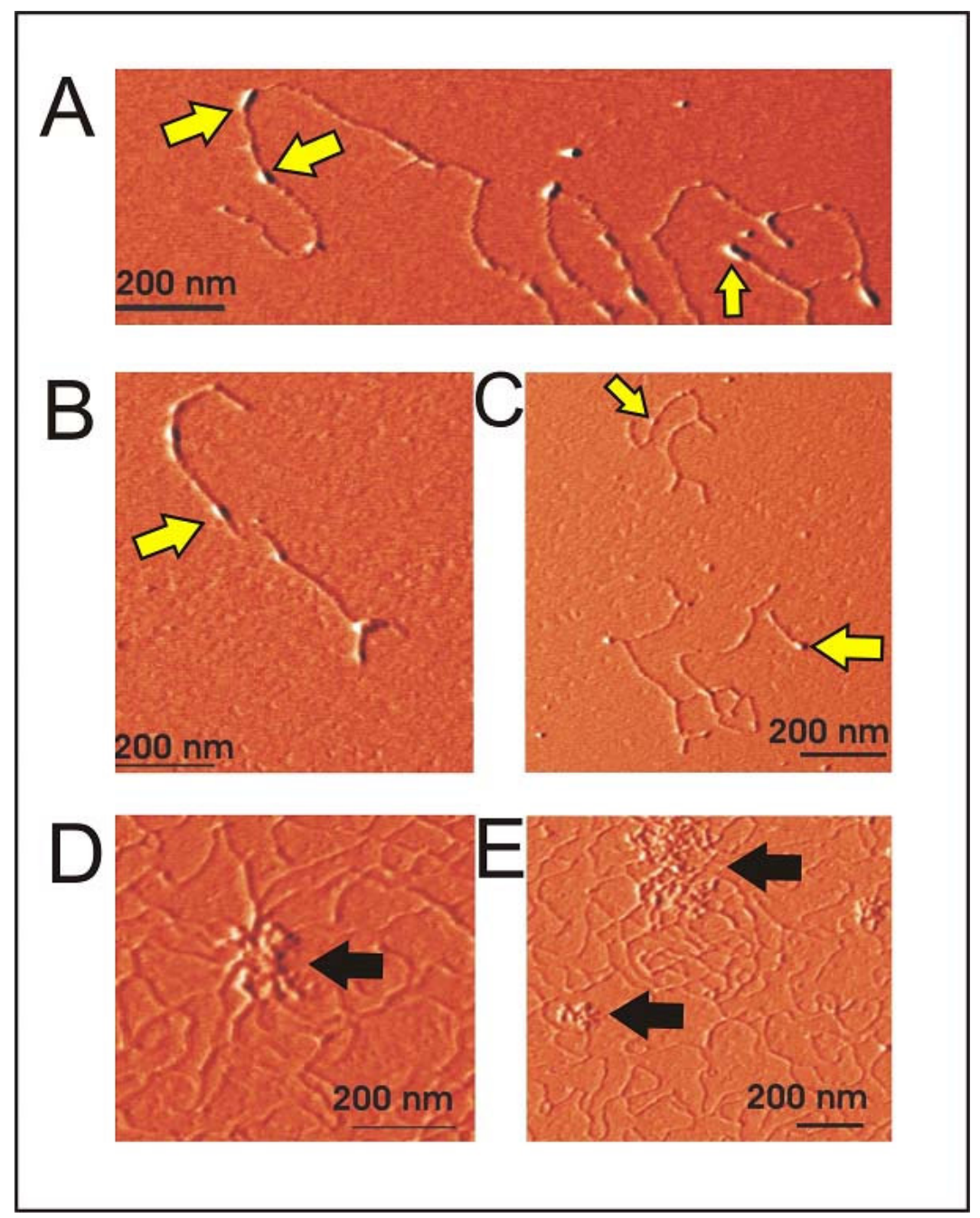

FIGURE 3. AFM 2D images of DNA obtained from the VBNC forms of $M$. gallisepticum S6 in air. $(\mathrm{A}-\mathrm{C})$ and $(\mathrm{D}, \mathrm{E}) \mathrm{DNAs}$ in concentration 0.15 and $0.45 \mathrm{ng} / \mu \mathrm{L}$, respectively. The yellow arrows, the sites of the possible binding DNA with Mg conglomerates; black arrows, the sites of DNA entwinement.

TABLE 1

Measured Height and Width of the DNA Molecules at Low Humidity (about $30 \%$ )

\begin{tabular}{lccc}
\hline \multicolumn{2}{c}{ DNA Parameter $(\mathbf{n m})$} & Vegetative Forms & VBNC Forms \\
\hline Height & & $0.461 \pm 0.141$ & $0.236 \pm 0.069$ \\
Width & $(1)$ & $15.547 \pm 2.002$ & $9.037 \pm 4.935$ \\
& $(2)$ & $2.221 \pm 0.286$ & $1.291 \pm 0.705$ \\
& $(3)$ & 4.318 & 3.082 \\
\hline
\end{tabular}

Note: (1) and (2) DNA width without and with the compilation adjustment (performed with the Nova 1.0.26 RC1 software), respectively. (3) DNA width calculated according to formula by Margeat et al.[6]. 
TABLE 2

Values of Kolmogorov-Smirnov (K-S) Test for Goodness of Fit to Normal Distribution and Student's $t$ Test for DNA Parameters

\begin{tabular}{lcccc}
\hline \multirow{2}{*}{$\begin{array}{l}\text { Type of } \\
\text { M. gallisepticum } \\
\text { S6 Cells }\end{array}$} & \multicolumn{2}{c}{ DNA Height } & \multicolumn{2}{c}{ DNA Width } \\
\cline { 2 - 5 } & \multicolumn{2}{c}{ Statistical Criterion } & \multicolumn{2}{c}{ Statistical Criterion } \\
\cline { 2 - 5 } & K-S & $\boldsymbol{t}$ & K-S & $\boldsymbol{t}$ \\
\hline VBNC forms & 0.17953 & 4,76681 & 0.20161 & \\
Vegetative forms & 0.15851 & & 0.28201 & 4,26639 \\
\hline
\end{tabular}

Note: $t$ presents values of Student's $t$ test for comparisons between the corresponding DNA parameters (height and width) of the VBNC forms and the vegetative forms of M. gallisepticum S6.

conglomerates. Their average height is $0.57 \pm 0.24 \mathrm{~nm}$. Because the average size of a single protein of 10 $\pm 100 \mathrm{kDa}$ is about $\sim 5 \mathrm{~nm}$ [9], it is difficult to think that these elevations were mediated by interaction of DNA with proteins. The performed deproteinization of our samples confirms this conclusion.

The most prominent changes between the DNA molecules extracted from the vegetative forms and the VBNC forms of $M$. gallisepticum S6 were detected while analyzing their height and width. The measured height of the DNA molecules extracted from the vegetative forms of M. gallisepticum S6 coincided with the well-accepted value for the height of the DNA as measured by AFM[10]. Concerning the DNA height measured for mycoplasma VBNC forms, we have to note that we controlled the level of humidity with the use of a hygrometer (the dependence of the DNA height on humidity in the environment is a well-known fact[11]) and the pressure of the cantilever was the same. Thus, the differences in height cannot be explained by the deformation of the DNA molecules due to these two factors. Because the technique of preparation of DNA samples was uniform for variants with the vegetative forms and the VBNC forms of M. gallisepticum S6 (the concentration of $\mathrm{MgCl}_{2}$ was the same), the analogous conclusion can be made regarding the DNA width: the observed differences are most probably attributed to biological features of DNA obtained from the VBNC forms of the mycoplasma. The principal ability for the existence of DNA of less width (about 1-1.5 nm) (and, correspondingly, diameter) was previously reported in early X-ray diffraction studies[12,13]. It is worth noting, however, that the compilation adjustment may provoke some errors due to drawbacks in mathematical algorithm and the real radius of cantilevers may differ from the stated value. Therefore, the use of ultrasharp cantilevers is desirable for the precise measurements in AFM.

Thus, we revealed differences in DNA sizes obtained from the vegetative forms and the VBNC forms of M. gallisepticum S6. Very likely, the reduced sizes of DNA from the VBNC forms of the bacterium are connected with the phenomenon of nanotransformation of mycoplasmas. To test whether these events may occur in other mycoplasma species, further studies are needed.

\section{ACKNOWLEDGMENTS}

We thank Dr. Olga A. Konovalova and Mr. Dmitry Nalimov (both from Kazan State University) for valuable help during work on the atomic force microscope. Also, we are grateful to Drs. Igor V. Yaminsky (Moscow State University), C.S. Delmonte (Open University, U.K. [Retired]), Yuri L. Lyubchenko (University of Nebraska Medical Center), Fernando Moreno-Herrero (Instituto Catalán de Nanotecnología), and Helen Hansma (University of California in Santa Barbara) for useful discussions. We thank Russian Fund for Basic Research (Project \#08-04-01047a) for supporting this work. 


\section{REFERENCES}

1. Razin, S.D., Yogev, D., and Naot, Y. (1998) Molecular biology and pathogenicity of mycoplasmas. Microbiol. Mol. Biol. Rev. 62, 1094-1156.

2. Chernov, V.M., Gogolev, Y.V., Mukhametshina, N.E., Abdrakhimov, F.A., and Chernova O.A. (2004) Mycoplasma adaptation to biogenic and abiogenic stressful factors; Acholeplasma laidlawii nannotransformation and minibodies. Dokl. Biol. Sci. 396, 251-254. [Russian]

3. Chernov, V.M., Gogolev, Y.V., Mukhametshina, N.E., Abdrakhimov, F.A., and Chernova, O.A. (2005) Adaptive reactions of mycoplasmas in vitro: "viable but unculturable forms" and nanocells of Acholeplasma laidlawii. Microbiologiya 74, 498-504. [Russian]

4. $\quad$ Chernov, V.M., Moukhametshina, N.E., Gogolev, Y.V., Nesterova, T.N., Trushin M.V., and Chernova, O.A. (2006) Differential amplification of Acholeplasma laidlawii PG8 $r r n \mathrm{~A}$ and $r r \mathrm{~B}$ nucleotide sequences during dissociation of the cell culture population. J. Rapid Methods Autom. Microbiol. 14, 369-376.

5. Chernov, V.M., Moukhametshina, N.E., Gogolev, Y.V., Nesterova, T.N., Trushin, M.V., and Chernova, O.A. (2007) Acholeplasma laidlawii PG8 culture adapted to unfavorable growth conditions shows an expressed phytopathogenicity. TheScientificWorldJOURNAL 7, 1-6.

6. Margeat, E., Le Grimellec, C., and Royer, C.A. (1998) Visualization of trp repressor and its complexes with DNA by atomic force microscopy. Biophys. J. 75, 2712-2720.

7. Lyubchenko, Y.L. (2004) DNA structure and dynamics. An atomic force microscopy study. Cell Biochem. Biophys. 41, 75-98.

8. Hansma, H.G., Laney, D.E., Bezanilla, M., Sinsheimer, R.L., and Hansma, P.K. (1995) Applications for atomic force microscopy of DNA. Biophys. J. 68, 1672-1677.

9. Halford, S.E. and Marko, J.F. (2004) How do site-specific DNA-binding proteins find their targets? Nucleic Acids Res. 32, 3040-3052.

10. Lyubchenko, Y.L. and Shlyakhtenko, L.S. (1997) Visualization of supercoiled DNA with atomic force microscopy in situ. Proc. Natl. Acad. Sci. U. S. A. 94, 496-501.

11. Moreno-Herrero, F., Colchero, J., and Bar A.M. (2003) DNA height in scanning force microscopy. Ultramicroscopy 96, 167-174.

12. Astbury, W.T. and Bell, F.O. (1938) X-ray study of thymonucleic acid. Nature 141, 747-748.

13. Riley, D.P. and Oster, G. (1950) X-ray diffraction studies of solutions of desoxyribonucleic acid (Na salt). Trans. Faraday Soc. 46, 791-792.

\section{This article should be cited as follows:}

Chernova, O.A., Trushin, M.V., Mouzykantov, A.A., and Chernov, V.M. (2008) Atomic force microscopy investigation of DNA extracted from the vegetative forms and the viable but nonculturable forms of Mycoplasma gallisepticum S6. TheScientificWorldJOURNAL 8, 1104-1110. DOI 10.1100/tsw.2008.143. 

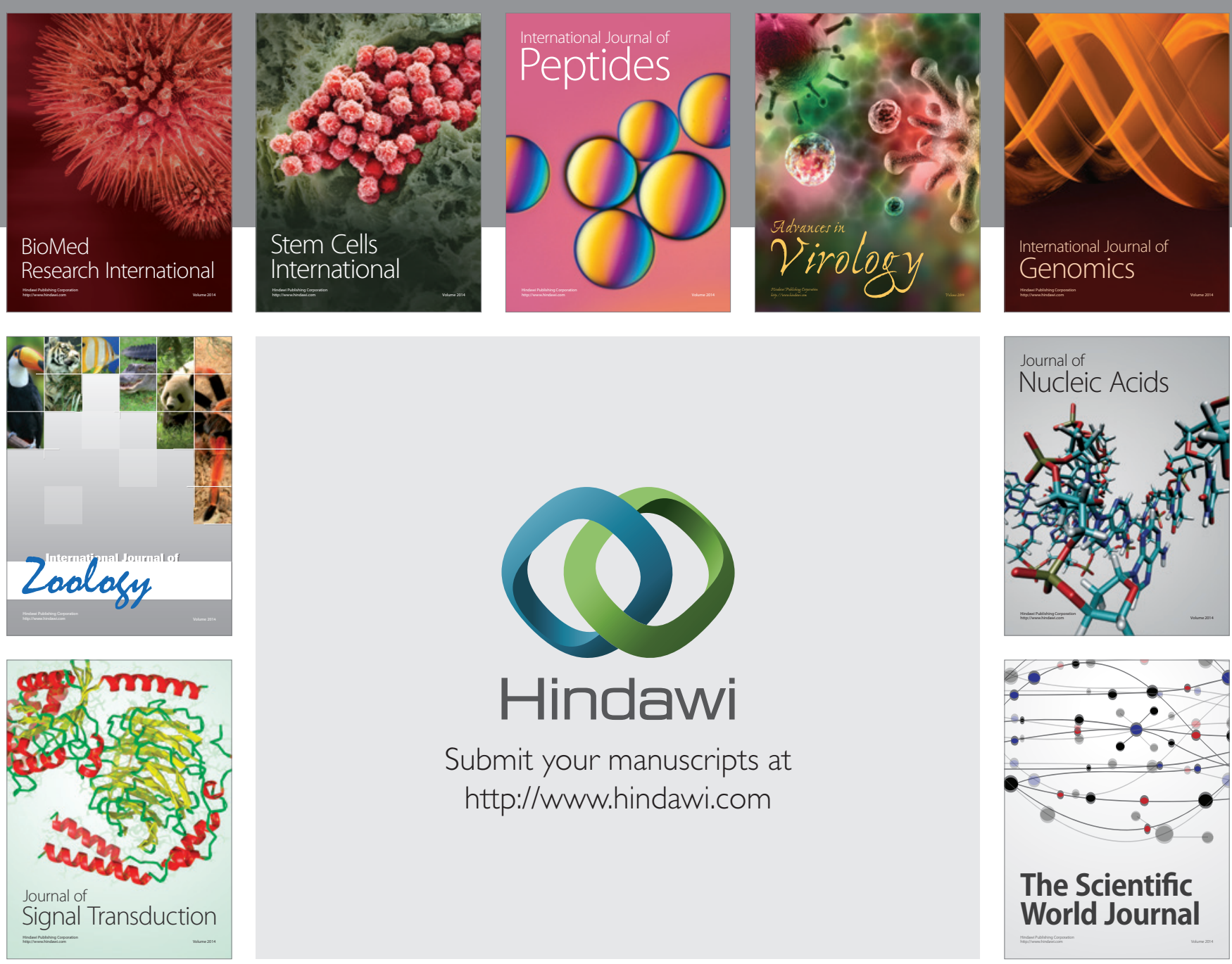

Submit your manuscripts at

http://www.hindawi.com
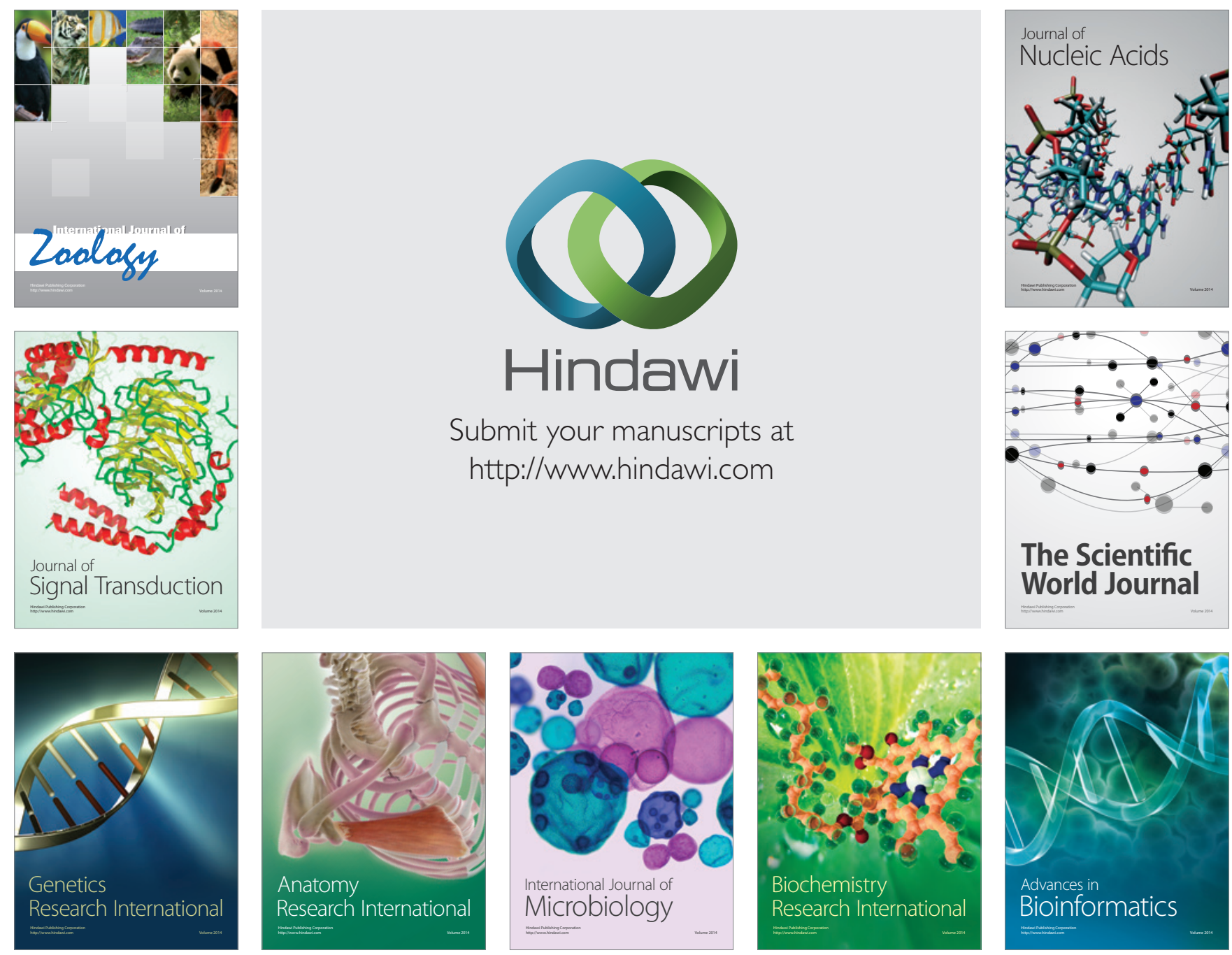

The Scientific World Journal
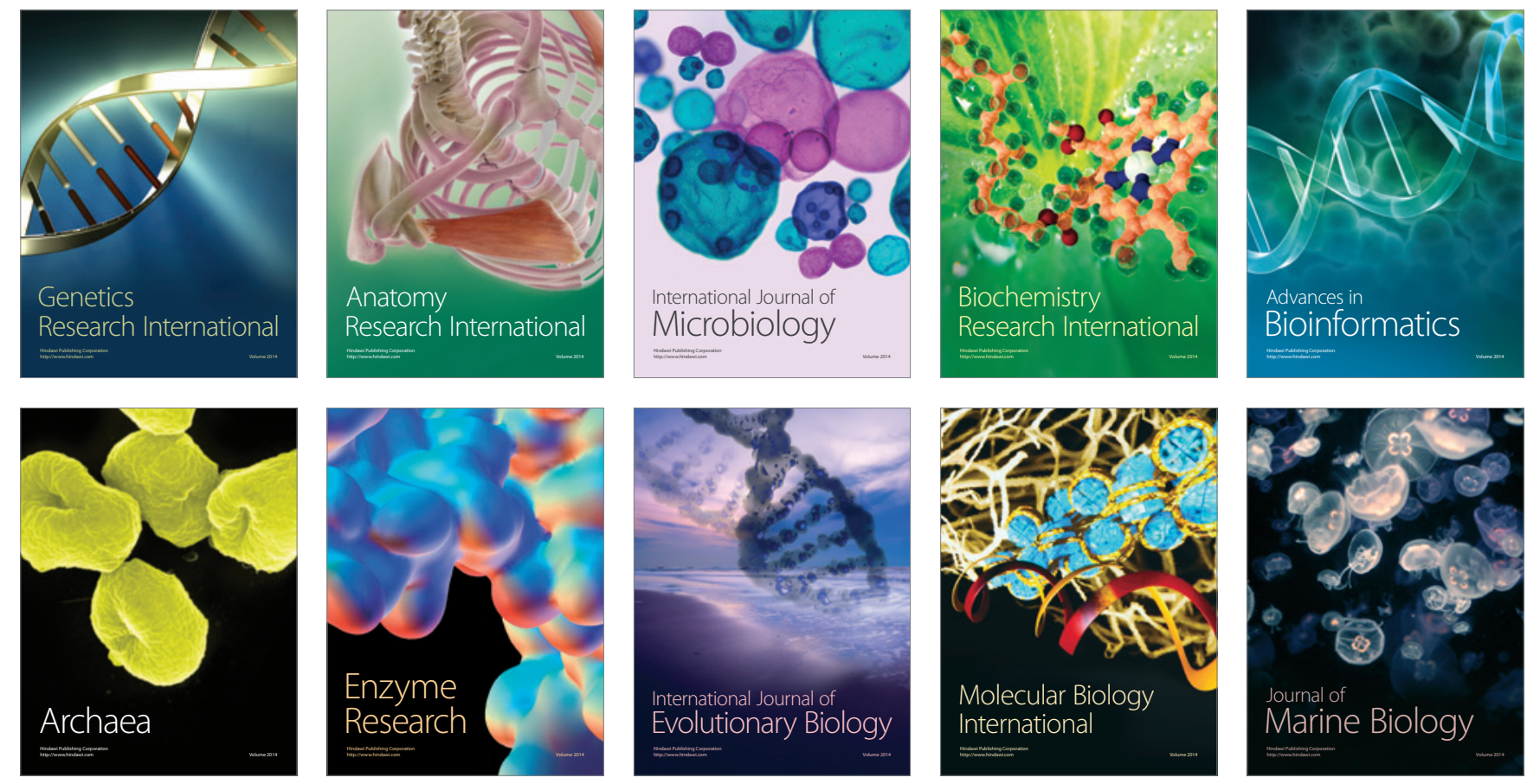